\title{
自転車用ディスクブレーキの鳴きの対策と解析*
}

\author{
中野寛*1, 末岡 淳 男*2, 劉孝宏*3 \\ 家藤 英 世*4, 折居利 昭*5, 中 江 貴 志*5
}

\section{Countermeasure and Analysis of Squeal in Bicycle Disk Brakes}

\author{
Yutaka NAKANO*6, Atsuo SUEOKA, Takahiro RYU, \\ Hideyo IEFUJI, Toshiaki ORII and Takashi NAKAE \\ ${ }^{* 6}$ Department of Mechanical Engineering, Kagoshima University \\ 1-21-40 Korimoto, Kagoshima-shi, Kagoshima, 890-0065 Japan
}

\begin{abstract}
This paper deals with the occurrence mechanism of the squeal phenomena generated in a new type of bicycle disk brake unit and its countermeasure experimentally and analytically. It was made clear that squeal was in-plane vibration in the direction of disk surface with frequency $650 \mathrm{~Hz}$ caused by frictional characteristics with negative slope with respect to the relative velocity, and was generated in the vibration system including brake unit and spokes, in the same manner of old type of disk brake unit. The countermeasure against squeal by using a dynamic absorber was conducted. The simple analytical model of the bicycle disk brake system was set up. Some features of squeal phenomena and the optimal design of dynamic absorber for quenching squeal were made clear analytically and it was confirmed that the analytical results agreed well with the experimental ones.
\end{abstract}

Key Words: Frictional Vibration, Self-Excited Vibration, Stability, Squeal, Dry Friction, Dynamic Absorber, Disk Brake, Bicycle

\section{1. 緒言}

自転車用ディスクブレーキは, 制動性能や放熱性の 高さ,メンテナンスが簡単であることから，近年ダウ ンヒル競技用のマウンテンバイクなどで主流となって いる. しかし，自動車用ディスクブレーキと同様に，

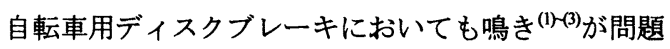
となる. 一方, 自転車用ディスクブレ一キは自動車の それと異なり, ロータの厚さが $2 \mathrm{~mm}$ 程度と非常に薄 いこと，ロータがハブを介してスポークで支持されて いるため，その取り付け剛性が低いことが特徽である. そのため, 自動車用ディスクブレーキの鳴き(4)(5) とは 異なる摩擦振動が発生する.

前報(の)で取り扱った自転車用ディスクブレーキに 対して，メンテナンスをより簡単にするため，特にロ

* 原稿受付 2005 年 11 月 10 日.

*1 正員, 鹿児島大学工学部( $-890-0065$ 鹿児島市郡元 1-2140).

*2 正員, 九州大学大学院工学研究院 ( 819-0395 福岡市西区 元岡 744).

*3 正員, 大分大学工学部(-870-1192 大分市旦野原 700).

*4 正員, 日産自動車 (株) (-104-8023 東京都中央区銀座 6-171).

*5 学生員, 九州大学大学院工学府.

E-mail : nakano@ mech.kagoshima-u.ac.jp
ータ形状の改善と, ホイールの軽量化に伴うスポーク 本数の削減が行われた. その結果, 本報で取り扱うデ イスクブレーキの鳴きは前報の鳴きとは異なる傾向を 示すことがわかった．そこで本報では，新型ディスク ブレーキユニットおよびベンチ実車実験装置(日)利用 した詳細な実験から鳴きの発生メカニズムを解明する とともに, 鳴き対策として動吸振器の最適な適用法を 示した. さらに, スポークを含む新型ディスクブレー キ系のモデル化を行い, ディスクブレーキの鳴きの再 現と動吸振器による鳴き抑制効果を解析的に取り扱い, 実験結果と解析結果のよい一致を確認した.

\section{2. 鳴き特性と発生メカニズム}

$2 \cdot 1$ ブレーキュニットの比較 図 1 に新型ブレー キュニットと前報(6)(7) で使用した旧型ブレーキユニッ トの構造的な違いを示す. 旧型ロー夕は摺動部と八ブ 取付部が一体となっており，ビスで固定する形式であ ったのに対して, 新型ロータは小穴が多く開けられた 摺動部と黒く見えるハブへの取付部がカシメを介して 結合された 2 段構造で, ハブにスプラインを介してロ 一タをワンタッチで取り付けられる構造になっている. 

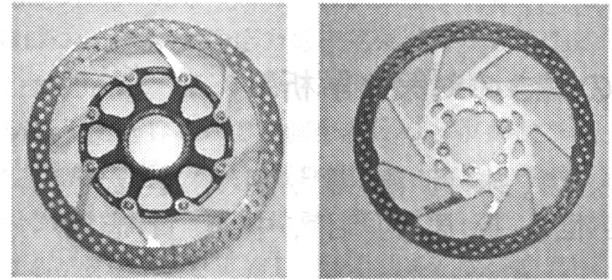

Rotor

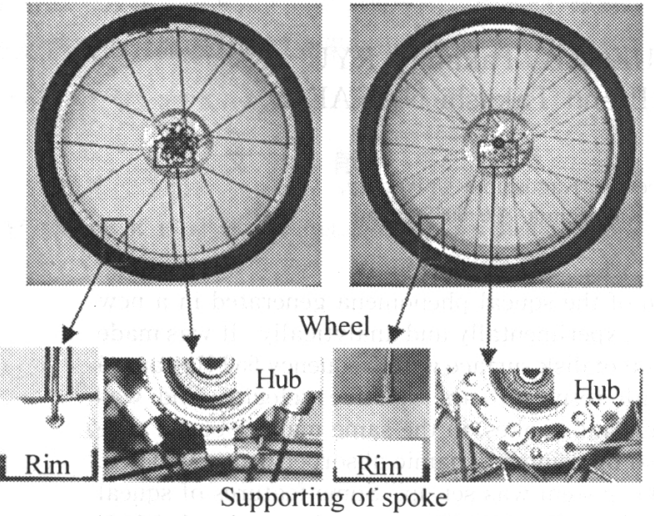

(a) New unit

(b) Old unit

Fig. 1 New and old models of bicycle disk brake unit

また，新型ロータの摺動部はステンレス製，ハブ取付 部はアルミ鋳造合金製である。

キャリパは旧型ブレーキユニットと同様に，ピスト ンを介してロータの両面をパッドで押さえつける対向 型であるが，ピストンの数が片側 2 本の対から片側 1 本の対に変更されている.

また, フロントホイールのスポークの直径は $2 \mathrm{~mm}$ で旧型車輪と同じであるが，本数は 32 本から 24 本に 减少している。新型車輪のスポークは図のように八ブ 側にねじが切られ，ニップルでハブと固定されており， リム側は引つ掛けるだけの構造をしている. 境界条件 は，リム側が単純支持，八ブ側が固定端に近い状態で ある。旧型車輪では反対に，八ブ側が単純支持，リム 側が固定端であった。また，旧型車輪では 2 本のスポ 一クが互いに交差して接触していたが，新型車輪では このようなスポーク間の接触は全くない。これらの構 造上の違いからいくつかの鳴き特性の違いが現れた．

$2 \cdot 2$ 実験装置実験には，前報(6)で用いたベンチ 実車実験装置を使用した。この装置は実車本体を実験 装置に取り込んだもので，旧車輪と旧ブレーキユニッ トから新車輪と新ユニットに取り替えた。実験は，車 輪回転数 $2 \mathrm{rps}$, ブレーキ油圧 1.0MPa とし, ともに一 定の条件で行った。図 2 に新型ブレーキユニットにお ける計測方法を示す。スポークやロータが回転してい

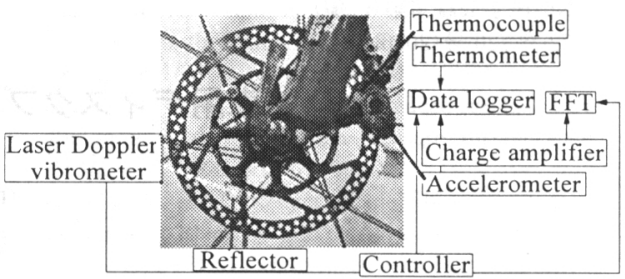

Fig.2 Measurement equipment

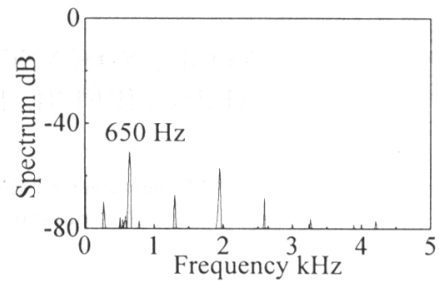

Fig.3 Squeal frequency

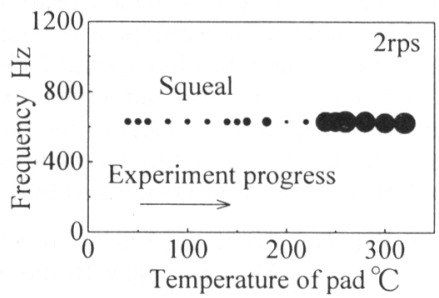

Fig.4 Relationship between pad temperature and squeal frequency

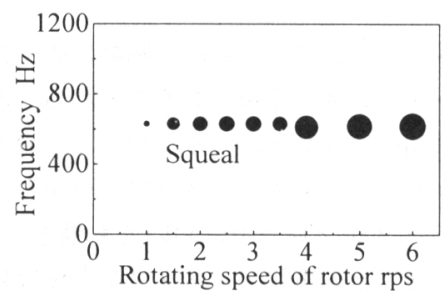

Fig.5 Relationship between rotating speed and squeal frequency

ることや，ロータが高温になることから，非接触で測 定が行えるレーザドップラ振動計を用い, ロータのロ 一夕面内方向と面外方向の振動速度を測定した. 図 2 には，ロータに小さいアルミの反射板を取り付け，そ のロータ面内方向の振動を測定している様子を示して いる. キャリパのロー夕面外方向振動は加速度計で計 測し, その加速度信号の周波数分析を行った. 自転車 用ディスクブレーキはロータが薄いことから, 制動時 の温度変化が激しいのが特徴である. そこで, パッド に熱電対をロウ付けしてパッド温度を測定した。

以後, 各部品のロー夕面内および面外の振動方向を 単に部品の面内方向および面外方向と呼ぶ. 
2.3 鳴きの特徴 図 3 は常温時, 鳴きが発生して いるときのキャリパの面外方向加速度の周波数分析結 果である. 図 4 はパッドの温度上昇に伴う鳴き振動数 の関係を調べた結果である，黒丸の大きさはキャリパ の面外方向加速度の大きさに対応している. 実験開始 から図中の矢印の方向に温度は上昇していくが, 鳴き 振動数は $650 \mathrm{~Hz}$ で，常にほぼ一定であることがわかる。 図 5 は, 鳴き振動数と車輪回転数の関係を調べるため に，回転数を $2 \mathrm{rps}$ から一時的に変化させたときの結果 である. 鳴き振動数は回転数にかかわらず $650 \mathrm{~Hz}$ でほ ぼ一定であるという自励振動の特性を示した. このと き, ロータの回転数領域は $1 \mathrm{rps} \sim 6 \mathrm{rps}$ である.これら の特徴は旧型ユニットと同じ傾向であった. 一方, 相 違点としては，これまでのブレーキユニットの鳴きは $1 \mathrm{kHz}$ と高く, 狭い高温領域で鳴き振動数の $1 / 2$ の振動 数をもつロータの面外方向の振動であるビビリが発生 していたが, 新型ユニットではこのような振動は発生 せず, $650 \mathrm{~Hz}$ の鳴きのみが常に発生した. しかし, 高 温になるに従って, 鳴きのレベルが上昇していた.

$2 \cdot 4$ 振動特性次に, 鳴き発生メカニズムを調 べるために，ブレーキをかけた状態で，ロータの打撃 試験を行った. 図 6 はロータの面外方向を打撃したと きの各モードの連成固有振動数を表す. 図 7 は, 図 6 の記号に対応する常温時のロータの面外方向連成固有 振動モードを示す，打摮試験では，温度と連成固有振 動数の関係を調べるために, 制動実験で温度を $400^{\circ} \mathrm{C}$ まで上昇させ，冷却過程で打撃を行い，各温度に対す る連成固有振動数を測定した. その結果, パッドの位 置は常に振動の節になっており, 固有モードには半径 節モード(の゙現れている. 実験から, 温度が高くなる につれて面外方向の連成固有振動数がわずかに低下す ることがわかった. 旧型ロータと比較して, 連成固有 振動数の低下は小さいものであったが, 温度変化に依 存しない鳴き振動数 $(650 \mathrm{~Hz})$ はロータ.の面外方向の固 有振動数とは直接関係しないことがわかった：しかし， $300^{\circ} \mathrm{C} \sim 400^{\circ} \mathrm{C}$ 付近になるとモード Dの 2.5 節モード ( 印)が $650 \mathrm{~Hz}$ に近づいていた. 図 4 の鳴き実験におい ても，高温領域においてキャリパの面外方向の振動レ ベルが大きくなっていることから少なからず影響があ ると考えられる.

次に，ロータの面内方向の打掱試験を行った.この 実験も温度との関係を見るために，常温で制動してい ないときと, はじめに制動実験で高温状態にして, そ の後制動を解除した $300^{\circ} \mathrm{C}$ 付近でのロータの面内方向 の固有振動数とを比較した．制動していないときの固 有振動数を測定したのは, 前報(クの実験結果から鳴き
はパッドとロータ間の円周方向相対速度に対して負の 勾配を有する乾性摩擦に起因した自励振動であること が推定されたためである. 図 8 に固有振動数の実験結 果を示す. 実験から, 面内方向に約 $650 \mathrm{~Hz}$ 付近の固有 振動数が存在して, この固有振動数は温度に依存しな いことが確認された. キャリパやパッドなどその他の 部品にも鳴き振動数 $650 \mathrm{~Hz}$ に近い固有振動数は見られ なかったことからも, 鳴き振動数はロータの面内方向 の固有振動数と関係していると結論付けた. さらに, ロータ面内摺動部上の 3 箇所およびハブ上の 1 箇所に 加速度計を取り付けて, 振動数 $655 \mathrm{~Hz}$ をもつロータお よびハブの面内振動モードを打撃試験により常温で測 定した. そのときの固有モードの測定結果を図 9 に示 す. 図の加速度計\#1 の振動を基準に位相差を測定した 結果, ロータおよびハブの $655 \mathrm{~Hz}$ の振動はほぼすべて 同位相であった. したがって，ロータと八ブは一体と なって面内方向に振動していることがわかる. 以上の 結果は, 旧型ブレーキュニットと同じであった(の).

2.5 鳴き発生メカニズム 次に, 鳴き発生時の口 一夕およびスポークそれぞれの面内方向および面外方 向の鳴き振動モードをレーザドップラ振動計で測定し た. ロータの面内方向およびスポークの面内・面外方 向の振動は, 回転中にアルミ反射板から反射した信号 を計測している. ロータの面内方向は図 2 に示すカシ

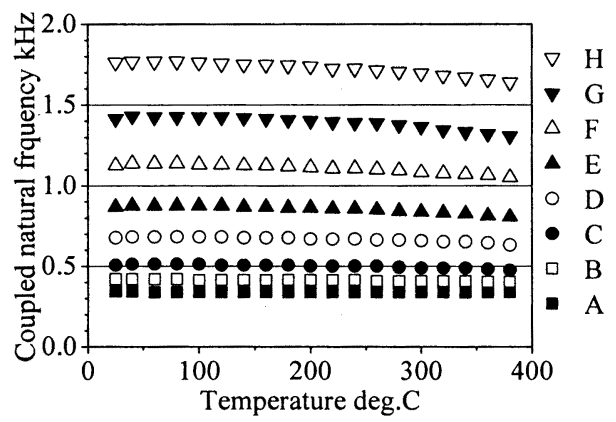

Fig.6 Coupled natural frequencies with dependence of temperature

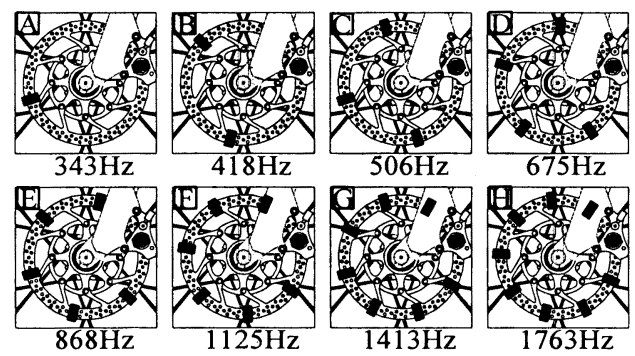

Fig. 7 Coupled natural vibration modes of rotor at $20^{\circ} \mathrm{C}$ 


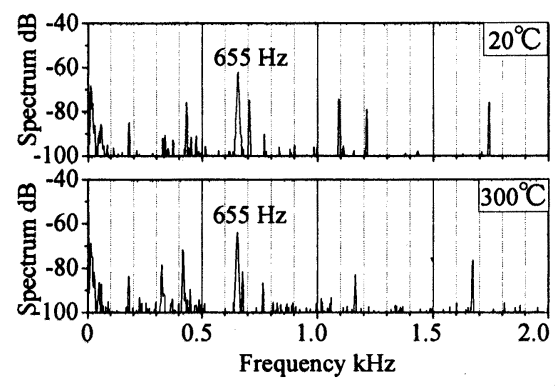

Fig.8 In-plane natural frequency of rotor on bench apparatus by actual bicycle

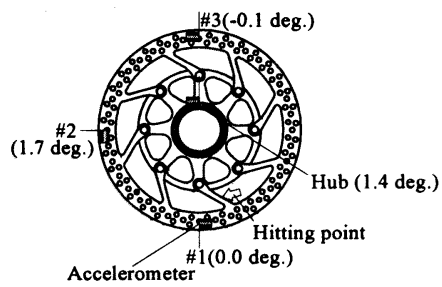

Fig. 9 Phase differences between rotor and hub in the in-plane direction

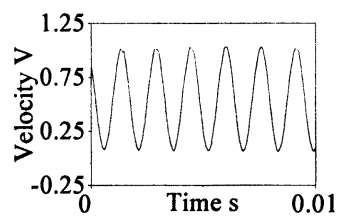

(a) In-plane

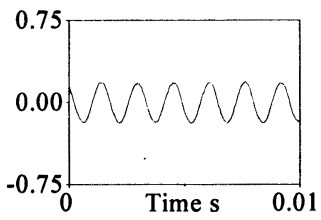

(b) Out-of-plane
Fig.10 Vibration waveforms of rotor in squeal $(1.25 \mathrm{~m} / \mathrm{s} / \mathrm{V})$ (a) In-plane

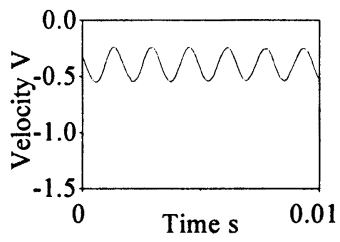

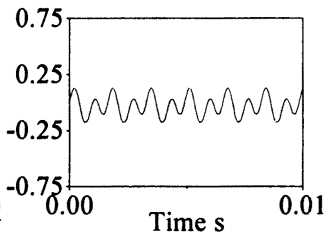

(b) Out-of-plane
Fig.11 Vibration waveforms of a spoke in squeal $(1.25 \mathrm{~m} / \mathrm{s} / \mathrm{V})$

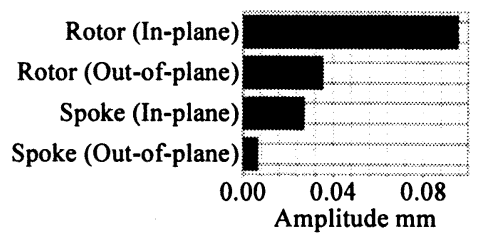

Fig.12 Amplitudes of rotor and spoke

メ部近傍，ロータの面外方向はロータの外周部，スポ 一クの面内・面外方向はスポークの振動が大きな位置
（ハブから $26 \mathrm{~mm}$ ）をそれぞれ測定した. 図 10 にロ 一タの, 図 11 にスポークの振動波形を示す、ロータ の面内方向と面外方向の振動を比較すると，ともに $650 \mathrm{~Hz}$ で振動しているものの, 振幅は面内方向の方が 十分に大きいことがわかる. スポークは面内方向, 面 外方向ともに鳴きと同じ振動数で振動しているが，面 外方向には鳴き振動数の 2 次成分が含まれている.

ロータおよびスポークの鳴き振動数 $650 \mathrm{~Hz}$ 成分の振 幅の比較を図 12 に示す. 図から，鳴き発生時には口 一タおよびスポークは面外方向よりも面内方向に大き く振動していることがわかる．また，ロータとスポー クの振幅を比較すると，面内・面外両方向ともロータ の方がスポークよりも大きな振動をしている．旧型ブ レーキュニットの鳴きの振動レベルがスポークの面 内・面外， ロータの面内, 口ータの面外の順に大きか ったことと比べると，大きく異なる結果となっだの.

新型ブレーキュニットを使って，スポークの固有振 動数を調べたところ, 鳴き振動数(約 $650 \mathrm{~Hz}$ )がスポー クの 1 次 (約 $490 \mathrm{~Hz}$ ) と 2 次 (約 $1 \mathrm{kHz}$ ) の固有振動数のほ ぼ中間に位置していた。これが鳴き発生時にスポーク の振動が小さい原因と考えられる. 新型モデルではス ポークの疲労破壊が全く起きていないのも，スポーク の振動が小さいことと関係していると考えられる( ${ }^{(0)}$.

以上, 新型ブレーキユニットにおいてもロータ面内 方向の振動が大きいことから, 鳴き発生メカニズムは 旧型ブレーキュニットの鳴き(6)(ク) と同様に, パッドと ロータの間の相対速度に対して負の勾配を有する乾性 摩擦に起因した自励振動であることが明らかになった。

\section{3. 動吸振器による鳴き抑制対策}

送電線などの流体励起振動の自励振動抑制に動吸振 器を適用した例 ${ }^{8}$ ははあるが, 摩擦自励振動抑制に動吸 振器を用いた例は少なく，その最適設計法を実験的お よび解析的に議論した研究も見当たらない。

自転車用ディスクブレーキの鳴きは乾性摩擦に起因 した自励振動で，ロータの面内方向主体の振動である ことが，前章の実験でわかった．そこで，この面内方 向の振動を抑制する動吸振器を製作した. 図 13 に実 験に用いた動吸振器とそれをブレーキユニットに取り 付けた概略図を示す．図に示すとおり動吸振器はマウ ント部分をハブに取り付ける構造となっており，片持 ちはり部分が動吸振器となっている. 図 8，9，10(a)か らロータと八ブは一体となって剛体ねじり振動をして いることが実験から確認されたことから，対策の施し やすい八ブに動吸振器を取り付けた．動吸振器の固有 振動数のチューニングは図 14 に示すとおり, 長穴に 

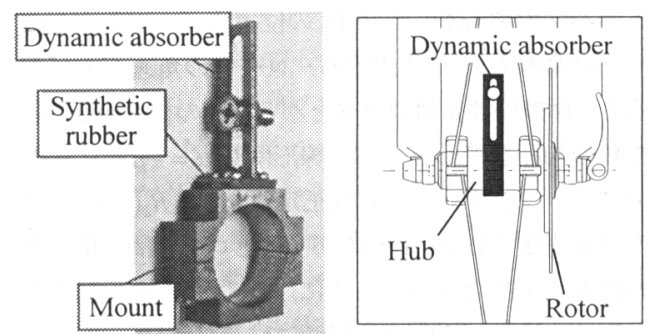

Fig.13 Dynamic absorber attached to disk brake system

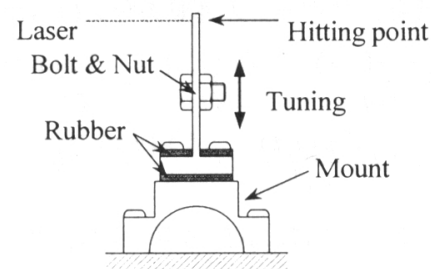

Fig.14 Impact testing of a dynamic absorber

取り付けたボルトとナットを上下させて行った。 また， 動吸振器に減衰を付加させるためにマウントと動吸振 器の間に合成ゴムを挟んでいる. 図 13 の動吸振器の モデルは自転車に実装寸るに值寸るものではなく，あ くまでも実験室においてその効果を確認することと， その最適設計法を検討するためのものである.

図 14 に示寸とおり, 動吸振器の打撃試験を行い, レーザドップラ振動計を用いて動吸振器の先端の振動 を計測して固有振動数と減衰比を計算した. 動吸振器 の主系に対する質量比は $4.7 \%$ で, その内訳は動吸振 器部の片持ちはり, ボルト, ナットが 29g, 主系は口 一タ, ハブ, スポークのブレーキユニットとマウント の質量の合計として $624 \mathrm{~g}$ である.

実験ではまず, 動吸振器を付けず, マウントのみを 八ブに取り付けた状態で鳴き実験を行い, 鳴きが発生 することを確認した，次に, 動吸振器を搭載し, その 固有振動数を変化させて, 鳴き発生の有無を調べた.

鳴き発生時のロータとキャリパの振動数は等しいため, 鳴きの振動数および振動レベルの測定は計測しやすい キャリパに取り付けた加速度計を用いて行なった.

マウントのみを取り付けたときの鳴き振動数は約 $640 \mathrm{~Hz}$ であった. 図 15 に動吸振器を取り付けたとき の実験結果を示寸、ゴムを付加していないときの動吸 振器の減衰比 $\zeta_{d}$ は 0.001 で, ゴムの枚数を増やしてい き, 減衰比を $0.06,0.10,0.13$ と大きくしていった. $f_{d}$ は動吸振器単体の固有振動数, $f^{\prime}$ は取り付けた動 吸振器の効果がなく鳴きが発生したときの振動数, $f$ はマウントのみを取り付けたときの鳴き振動数 (640 $\mathrm{Hz}$ )を表し，各軸を無次元化している. 図中の白丸の
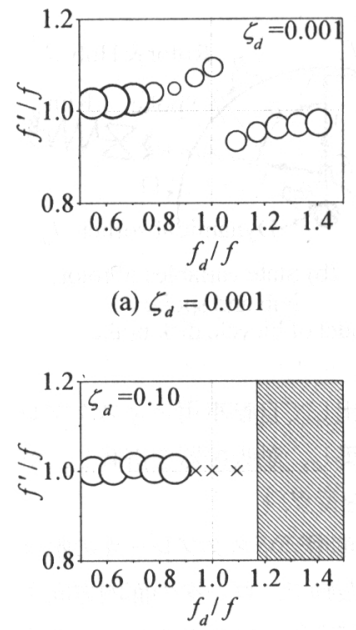

(c) $\zeta_{d}=0.10$ (a) $\zeta_{d}=0.001$

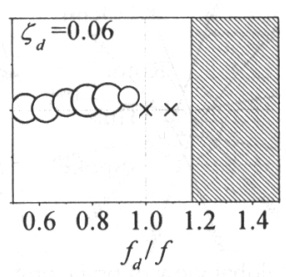

(b) $\zeta_{d}=0.06$
Fig. 15 Occurrence of squeal and its frequency with dynamic absorber

位置は動吸振器の固有振動数をチューニングしたとき に発生する鳴き振動数を表しており，丸が大きいほど 振動レベルは大きい. 図 15(b), (c), (d)の網掛け部分は動 吸振器の構造上チューニングが行えず実験ができなか った領域を示す. 図 15 から, 減衰比 $\zeta_{d}$ が小さい 0.001 のときは, 動吸振器の固有振動数を鳴き振動数に対し てどのようにチューニングしても鳴きが収まらず, 動 吸振器の効果はないことがわかる. 動吸振器の減衰比 を 0.06 と大きくし， ×印で示寸横軸の位置に動吸振器 の固有振動数をチューニングすると鳴きは抑制された. このとき，鳴き振動数のピークは全く見られず，鳴き 音も聞こえなかった，減衰比を大きくすると鳴きが生 じないチューニング振動数範囲がさらに広がった．し かし, 減衰比を大きくして 0.13 程度にしても抑制範囲 が広がる傾向を示さなかった，減衰比を大きくしすぎ ると動吸振器と主系が一体となって振動を始めるため, 減衰の効果は小さくなると予想される.したがって, 動吸振器によって鳴きを抑制するためには, 動吸振器 の固有振動数を鳴きの振動数付近にチューニングする とともに, 動吸振器に必ず減衰を付加する必要がある. 今回の実験では, 最適な減衰比が約 0.10 0.13 付近に存 在することがわかった。この值は 1 自由度系の強制振 動に対する質量比 $5 \%$ における動吸振器の最適减衰比 とほぼ一致する。

\section{4. 数値解析}

第2章では, 自転車用ディスクブレ一キの鳴き発生メ カニズムを実験的に明らかにした. 本章では発生メカニ 


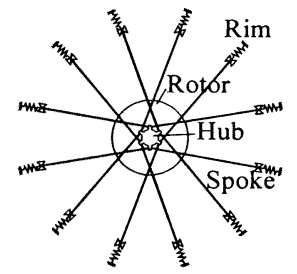

(a) Global view of brake unit

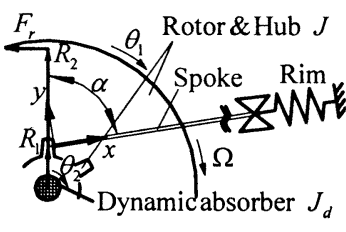

(b) State variables of rotor, hub and spoke

Fig.16 Analytical model of bicycle disk brake
ズムの本質となるものを抽出して自転車用ディスクブレ 一キの鳴き解析モデルを構築し, 動吸振器を搭載した解 析結果と実駼結果との比較を行う.

$4 \cdot 1$ 解析モデル 自転車用ディスクブレーキの鳴き は乾性摩擦に起因した自励振動で, ロータの面内方向主 体の振動である. また, 自転車用ディスクブレーキの鳴 きは，ロータおよびキャリパのブレーキュニットのみな らずスポークを含む系を考慮する必要がある.これは， スポークを含まないブレーキユニットのみを取り出した 実験装置包では実車で発生する鳴き $(650 \mathrm{~Hz})$ が再現できな かったことに基づいている.

図 16(a)に解析モデルの全体図を示す，モデル化に際し て以下のような簡略化を行う.

（1）ロータと八ブはロータの面内方向には一体となっ てねじり振動をしており，剛体とみなし得る. ロータの 面外方向の振動は小さく，鳴きとは本質的に関倸してい ないので, 解析では無視する.

（2）スポークは長手方向にはばねとしてハブを支持し， 面内方向には曲げ振動が可能な張力のかかったはりと考 える. スポークの振動特性は 24 本すべて同じとする.

（3）スポークのハブ側を固定端，リム側を単純支持と する. また，スポーク長手方向に関してはリムの剛性を 考慮して, リム側をばね支持されているとする.

（4）キャリパとパッドの質量は無視する.

（5）ねじり振動用の動吸振器がハブの回転軸に取り付 けられ，ねじり振動を防止する. 解析では, 実験で用い た片持ちはり様動吸振器とは異なる形式を採用する.

図 16(b)にロータ，ハブ，スポークの各部の変位および 働く力を示す. 八ブの中心に原点をとる. 半径 $R_{1}$ の位置 にハブの法線方向に対して傾き $\alpha$ で 24 本のスポークが 八ブの円周上に等間隔に取り付けられている. スポーク はロータ側とその反対側に各 12本ずつあるが，解析では ロータの面外方向の奥行きを考慮せず, 同じ位置にスポ 一クが 2 本ずつ取り付けられていると考える. ロータと 八ブのねじれ角を $\theta_{1}$, 任意のスポークの長手方向座標を $x$, それに垂直な座標を $y$, 横変位を $y(x, t)$ とする. ま た, ハブの中心に取り付けた動吸振器のねじれ角を $\theta_{2}$ と
する. ハブの中心から半径 $R_{2}$ の位置にパッドを介して ロータに摩擦力 $F_{r}$ が作用する. ロータの角速度を $\Omega$ と すると, 摩擦㐿数 $\mu$ はロータとパッド間の相対速度に対 して負の勾配を持つとして, 線形関数 $\mu=-\mu_{1} v+\mu_{0}$ で 近似する.ここで, $\mu_{0}, \mu_{1}$ は正定数, $v=R_{2}\left(\Omega+\dot{\theta}_{1}\right)$ は その相対速度である. 1 つのパッドとロータ間に衝く摩 擦力は $F_{r}=\mu N$ となる. ここに, $N$ はロータ片面に作 用するパッドの一定押し付け荷重である.

$4 \cdot 2$ 運動方程式 スポークを張力のかかったはり と考えると, スポークの運動方程式はスポーク共通に,

$$
\begin{gathered}
\rho A \frac{\partial^{2} y(x, t)}{\partial t^{2}}+c_{1} \frac{\partial y(x, t)}{\partial t}-c_{2} \frac{\partial^{3} y(x, t)}{\partial t \partial x^{2}} \\
\quad+E I \frac{\partial^{4} y(x, t)}{\partial x^{4}}-T \frac{\partial^{2} y(x, t)}{\partial x^{2}}=0
\end{gathered}
$$

で表される.ここに， $\rho$ はスポークの密度，Aは断面積， $E$ は緃弾性係数, $I$ は断面二次モーメント, $T$ は張力 である. また，スポークの横変位に対する減衰 $c_{1}$ および 曲げに対する減衰 $c_{2}$ を考虑している.

式(1)の解を次式の形式で表す.

$$
y(x, t)=Y(x) e^{\lambda t}
$$

式(2)を式(1)に代入し， $Y(x)$ を求めると,

$$
Y(x)=C_{1} e^{\frac{k_{1} x}{l}}+C_{2} e^{\frac{k_{2} x}{l}}+C_{3} e^{\frac{k_{3} x}{l}}+C_{4} e^{\frac{k_{4} x}{l}}
$$

ここに，入は複素固有值，lはスポークの長さ， $C_{1}$, $C_{2}, C_{3}, C_{4}$ は積分定数, $k_{1}, k_{2}, k_{3}, k_{4}$ は次式の中の $2 つ$ の複号士の符号を組み合わせて求められる.

$$
\begin{aligned}
& \left(k_{1}, k_{2}, k_{3}, k_{4}\right) / l \\
& = \pm \sqrt{\frac{1}{2}\left(\frac{c_{2} \lambda+T}{E I} \pm \sqrt{\left(\frac{c_{2} \lambda+T}{E I}\right)^{2}-4 \frac{\rho A \lambda^{2}+c_{1} \lambda}{E I}}\right)}
\end{aligned}
$$

一方, スポークの境界条件は次のようになる.

$$
\left.\frac{d Y(x)}{d x}\right|_{x=0}=0, Y(l)=0,\left.\frac{d^{2} Y(x)}{d x^{2}}\right|_{x=l}=0
$$

ただし，ハブのねじれ角とハブ側スポークの横変位の 適合条件は次式のようになる.

$$
y(0, t)=R_{1} \theta_{1}(t) \cos \alpha
$$

八ブとロータは面内方向の剛体ねじり振動を行ってい るので, 運動方程式は次式となる.

$$
\begin{aligned}
& J \ddot{\theta}_{1}+C \dot{\theta}_{1}-2 \mu_{1} R_{2}^{2} N \dot{\theta}_{1}+C_{d}\left(\dot{\theta}_{1}-\dot{\theta}_{2}\right) \\
& +K_{d}\left(\theta_{1}-\theta_{2}\right)=-\left.24 E I R_{1} \cos \alpha \cdot \frac{\partial^{3} y(x, t)}{\partial x^{3}}\right|_{x=0} \\
& +\left.24 E I \frac{\partial^{2} y(x, t)}{\partial x^{2}}\right|_{x=0}-\frac{24 \beta E A}{l} R_{1}^{2} \theta_{1} \sin ^{2} \alpha \\
& -2 \mu_{0} N R_{2}+2 \mu_{1} N R_{2}^{2} \Omega
\end{aligned}
$$

ここに, $J$ はロータと八ブを含めた回転軸回りの慣 
性モーメント， $C$ はロータと八ブの回転運動に関する 减衰を表す、スポーク長手方向のばねとリム側の支持 ばねは直列で，リム側のばね定数がスポークのばね定 数 $E A / l$ よりも小さくなっており, その全体の補正值 をパラメータ $\beta$ を使って $\beta E A / l$ で表す. $C_{d}$ と $K_{d}$ は 動吸振器の回転の減衰係数とばね定数である.

動吸振器の慣性モーメントを $J_{d}$ とすると, 動吸振 器の運動方程式は, 次式となる.

$$
J_{d} \ddot{\theta}_{2}+C_{d}\left(\dot{\theta}_{2}-\dot{\theta}_{1}\right)+K_{d}\left(\theta_{2}-\theta_{1}\right)=0
$$

式(8)の解 $\theta_{2}$ も $C_{5}$ を定数として, 次の形式で求める.

$$
\theta_{2}(t)=C_{5} e^{\lambda t}
$$

式 $(7),(8)$ 变数 $\theta_{1}, \theta_{2}$ を次のように一定值 (大文字 の変数）と変動量（チルダ付き変数）の和で表す.

$$
\theta_{1}=\Theta_{1}+\tilde{\theta}_{1}, \theta_{2}=\Theta_{2}+\tilde{\theta}_{2}
$$

式(5), (7), (8)から, 変動量に関する方程式を行列 形式にまとめると, 次のようになる.

$$
\begin{aligned}
& {\left[\begin{array}{lllll}
k_{1} & k_{2} & k_{3} & k_{4} & 0 \\
e^{k_{1}} & e^{k_{2}} & e^{k_{3}} & e^{k_{4}} & 0 \\
k_{1}^{2} e^{k_{1}} & k_{2}^{2} e^{k_{2}} & k_{3}^{2} e^{k_{3}} & k_{4}^{2} e^{k_{4}} & 0 \\
A_{1} & A_{2} & A_{3} & A_{4} & D \\
B & B & B & B & F
\end{array}\right]\left[\begin{array}{l}
C_{1} \\
C_{2} \\
C_{3} \\
C_{4} \\
C_{5}
\end{array}\right]=\mathbf{0} \ldots(11) } \\
& \begin{array}{l}
A_{i} \\
=
\end{array} J^{2}+\left(C+C_{d}-2 \mu_{1} R_{2}^{2} N\right) \lambda+\frac{24 \beta E A R_{1}^{2} \sin ^{2} \alpha}{l} \\
& +K_{d}+\frac{24 E I k_{i}^{3} R_{1}^{2} \cos ^{2} \alpha}{l^{3}}-\frac{24 E I k_{i}^{2} R_{1} \cos \alpha}{l^{2}} \\
B & =-\left(C_{d} \lambda+K_{d}\right), D=-\left(C_{d} \lambda+K_{d}\right) R_{1} \cos \alpha \\
F & =\left(J_{d} \lambda^{2}+C_{d} \lambda+K_{d}\right) R_{1} \cos \alpha
\end{aligned}
$$

式(11)の定数 $C_{1}, \cdots, C_{5}$ が非自明解を持つための条件, すなわち, 特性方程式は次式となる.

$$
\operatorname{det}\left[\begin{array}{cccc:c}
k_{1} & k_{2} & k_{3} & k_{4} & 0 \\
\vdots e^{k_{1}} & e^{k_{2}} & e^{k_{3}} & e^{k_{4}} & 0 \\
\vdots k_{1}^{2} e^{k_{1}} & k_{2}^{2} e^{k_{2}} & k_{3}^{2} e^{k_{3}} & k_{4}^{2} e^{k_{4}} & 0 \\
A_{1} & A_{2} & A_{3} & A_{4} & D \\
\hdashline B & B & B & B & F
\end{array}\right]=0
$$

4.3 数値計算結果 Newton-Raphson 法を用いて式 (13)の固有值入を計算し, 安定性を調べた. 収束した 固有値入の実部が正となるときの虚部を $2 \pi$ で除して 不安定系の振動数を求め, 鳴き振動数と比較する. 計 算に使用したパラメータを表 1 に記す。摩擦係数の定 数 $\mu_{0}, \mu_{1}$ は前報(6)の摩擦係数測定結果から決定した.

まず, 動吸振器とマウントを付けていない状態で安 定判別を行った. そのとき, 特性方程式は式(13)の点 線で囲まれた $4 \times 4$ の行列式 $=0$ となる. 計算結果から
Table 1 Values of parameters

\begin{tabular}{l|l|l|l}
\hline$A$ & $3.14 \times 10^{-6} \mathrm{~m}^{2}$ & $N$ & $500 \mathrm{~N}$ \\
\hline$C$ & $0.058 \mathrm{~N} \cdot \mathrm{m} \cdot \mathrm{s}$ & $R_{1}$ & $26 \mathrm{~mm}$ \\
\hline$c_{1}$ & $4.8 \times 10^{-2} \mathrm{~N} / \mathrm{m}^{2} \cdot \mathrm{s}$ & $R_{2}$ & $73 \mathrm{~mm}$ \\
\hline$c_{2}$ & $1.8 \times 10^{4} \mathrm{~N} \cdot \mathrm{s}$ & $T$ & $1000 \mathrm{~N}$ \\
\hline$E$ & $1.97 \times 10^{11} \mathrm{~N} / \mathrm{m}^{2}$ & $\alpha$ & 80 degrees \\
\hline$I$ & $7.85 \times 10^{-13} \mathrm{~m}^{4}$ & $\beta$ & 0.28 \\
\hline$J$ & $6.20 \times 10^{4} \mathrm{~kg} \cdot \mathrm{m}^{2}$ & $\mu_{0}$ & 0.5 \\
\hline$J_{d}$ & $3.10 \times 10^{-5} \mathrm{~kg} \cdot \mathrm{m}^{2}$ & $\mu_{1}$ & $0.07 \mathrm{~s} / \mathrm{m}$ \\
\hline$l$ & $268 \mathrm{~mm}$ & $\rho$ & $8030 \mathrm{~kg} / \mathrm{m}^{3}$ \\
\hline
\end{tabular}

初期值 $\lambda_{0}$ の值に関わらず, 不安定となる固有値 $\lambda$ か ら求めた振動数は約 $650 \mathrm{~Hz}$ のみで, 実際に発生する鳴 き振動数と一致した.

次に, スポークの不安定モードを求めた. 固有值 $\lambda$ の実部が正となるとき, 式(11)の上 4 つの式から定数 $C_{1}, C_{2}, C_{3}, C_{4}$ を求め, 式(3),(2) に代入してスポークの 鳴き発生時の振動モードを求めた. 図 17 に を0とし, 虚部だけを考慮した鳴き振動波形の結果を 示す. 横軸はスポークの長手方向の位置を表し, ハブ 側が左側, リム側が右側である. 縦軸はある位置の振 幅を規定したモード振幅を表す. 図 17 は $1 / 6$ 周期毎の 波形を示しており, 図中の番号は経過時刻順を表す. 図17からスポークの振動モードは 1 次と 2 次の中間の モードである. 図 17 から複素モードの特徵である振 動モードの節が明確に現れない様子が伺える. 一方, 実験で鳴き発生中のスポークの振動モードをドップラ 振動計で測定した. 反射板が小さいため, 面内方向の スポークのハブ側半分だけを測定した結果, 振動モー ドは 1 次と 2 次の中間のモードであることがわかり， 解析結果と実験結果との良い一致が確認できた。 また, この複素モードでは, ロータ摺動部の面内方向振動振 幅が最も大きいことも確かめられた.

$\mathbf{4 \cdot 4}$ 動吸振器による鳴き抑制次に, 動吸振器 による不安定系の安定化, すなわち, 鳴き抑制効果と の相関を調べた. 動吸振器の慣性モーメント $J_{d}$ を主 系の慣性モーメントJの $5 \%$ として計算する.また, 動吸振器の回転ばね定数および減衰係数を,

$$
K_{d}=\left(2 \pi f_{d}\right)^{2} \times J_{d}, C_{d}=2 \zeta_{d} \sqrt{J_{d} K_{d}}
$$

の関係から求めることにし, 動吸振器の固有振動数 $f_{d}$ を変化させてチューニングを行う.ささら, 動吸 振器の減衰比 $\zeta_{d}$ の值を変え, 鳴き抑制効果との関係 を確認する. 図 18 に動吸振器の固有振動数を変化さ せたときに不安定となる振動数比を記号ロでプロット している. (a) と(b)は動吸振器の減衰比がそれぞれ 0.001 と 0.1 のときである. 図 18(a), (b)から, 減衰比が 


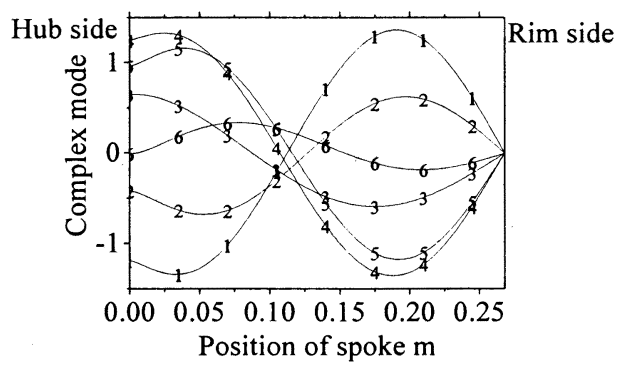

Fig.17 Unstable mode of spoke

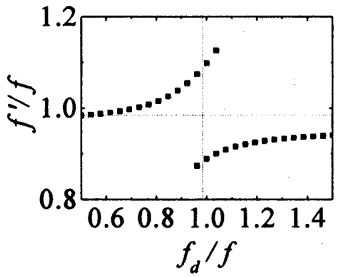

(a) $\zeta_{d}=0.001$

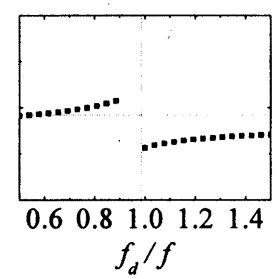

(b) $\zeta_{d}=0.1$
Fig.18 Unstable frequency with dynamic absorber

小さいときは動吸振器の固有振動数の変化に関わらず, 系は不安定（鳴きが発生）になるが，減衰比を 0.1 程 度に大きくすると系が安定（鳴きが不発生）になる動 吸振器の固有振動数チューニング領域が鳴き振動数付 近に現れており，実験結果と良い相関を示している.

図 19 は, 主系に対する動吸振器の慣性モーメント 比を $5 \%$ と $10 \%$ にしたとき, 動吸振器のチューニング 振動数と減衰比の関係を調べた結果である. 白い領域 は安定な領域を示す。図 19 から, まず慣性モーメン ト比に関わらず, 動吸振器の固有振動数を鳴きの振動 数付近にチューニングすることが必要であること，さ らに減衰がないとき，または減衰比が小さ過ぎるとき は動吸振器による鳴き抑制効果は得られないことがわ かる. また, 図 19(a)の慣性モーメント比 5\%のとき, 動吸振器のチューニングによる安定領域が最も広いの は減衰比 $\zeta_{d}$ が 0.13 0.14 であり, 動吸振器の質量比と 慣性モーメント比の違いはあるものの，実験から求め た最適な減衰比 $0.1 \sim 0.13$ と近い值を示した.

以上のように，自励振動を動吸振器で抑制する場合， 動吸振器のサイズ, 動吸振器のチューニングおよび減 衰の大きさの決定が重要な要素となる. その内, 自励 振動の種類によっては動吸振器の減衰が少ない方がよ い場合もあるが，乾性摩擦による自励振動の場合は動 吸振器の减衰に最適值が存在することが判明した。 ま た, 動吸振器によって鳴きが発生する不安定系から鳴 きが発生しない安定系に移行させたとき，系自身が安 定系になったわけであるから，動吸振器を含む系全体

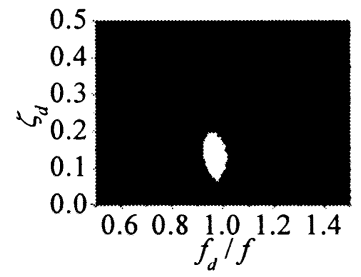

(a) $J_{d} / J=0.05$

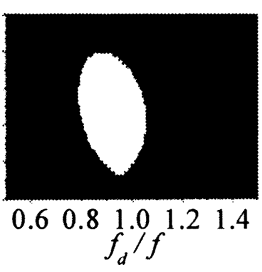

(b) $J_{d} / J=0.1$
Fig.19 Stable region dependent on tuning frequency and damping ratio

が振動しない.したがって，動吸振器のばねの疲労破 壊の問題はない.

\section{5. 結 言}

新型ブレーキュニットに変更された自転車用ディス クブレーキの鳴き現象と対策を実験および解析から解 明した. 得られた結果は以下のようにまとめられる.

（1）新型ブレーキュニットにおいても鳴きはロー タとパッドの乾性摩擦に起因した自励振動であり，鳴 き発生時にはロータの面内方向の振動が主体である.

（2）鳴き発生時にスポークも鳴き振動数で振動し ているが，ロータの振動振幅ほどは大きくなくスポー クの疲労破壊には至らなかった。

（3）動吸振器によって鳴きを完全に抑制すること ができた．鳴きを抑制するためには動吸振器の固有振 動数を鳴き振動数付近にチューニングする必要がある ことと, 動吸振器にある程度減衰を付加しなければ効 果がないことがわかった，減衰は大き過ぎても効果は なく, その值には最適值が存在する.

（4）スポークを含むブレーキュニット系で自転車 用ディスクブレーキの鳴き解析モデルを構築した。解 析では乾性摩擦による自励振動系を考え，ロータの面 内方向の振動のみにしぼり，スポークは張力のかかっ たはりでモデル化し，解析を行った．その結果, 解析 結果と実験結果との良い一致を確認した.

（5）解析モデルにも動吸振器を適用して, 動吸振 器の最適設計法を示した。乾性摩擦に起因した自励振 動系を動吸振器で抑制するためには，動吸振器を鳴き 振動数付近にチューニングして，適度な減衰を付加す る必要があることを解析的に確認した。 またこれら の結果と実験結果との良い一致も確認した.

\section{文献}

(1) Hayashi, H., Tribology of Brakes, Bicycle Brakes (in Japanese), Journal of Japanese Society of Tribologists, Vol.41, No.4 (1996), pp.305-310.

(2) Ooya, T., Ooki, T., and Hattori, Y., Study on Squeal in Bicycle 
Caliper Brake I (Study on Safety and Control Performance of Bicycle), Bicycle Technology Information, Vol.9 (1980), pp.3236.

( 3 ) Ooya, T., Ooki, T., and Hattori, Y., Study on Squeal in Bicycle Caliper Brake II (Study on Safety and Control Performance of Bicycle) (in Japanese), Bicycle Technology Information, Vol.15(1982), pp.37-43.

(4) Sueoka, A., Ryu, T., Shirozu, K., and Ichiba, Y.,Squeal of a Disk Brake of Floating Type for Cars (1st Report, Relationship between Occurrence of Squeal and Contact Reigion between Rotor and Pads in Experiment) (in Japanese), Trans. JSME, Series C, Vol.67, No.658 (2001), pp.1727-1734.

( 5 ) Steel, P. D., Fieldhouse, J. D., Talbot, C. J. and Crampton, A., In-plane vibration investigations of a noisy disk brake, In Barton DC and Blackwood A.(Eds) Braking 2004, Leeds, (2004), 103-112, Bury St Edmunds and London: Profes- sional Engineering Publishing.

(6) Ryu, T., Sueoka, A., Shirozu, K., Emura, A. and Nakano, Y., Experimental Investigation on Squeal and Chatter Phenomena in Bicycle Disk Brakes (Part 1, Regeneration Experiments of Squeal and Chatter and Their Characteristics) (in Japanese), Trans. JSME, Series C, Vol.70, No.689(2004), pp.30-37.

( 7 ) Sueoka, A., Ryu, T., Shirozu, K., Emura, A. and Nakano, Y., Experimental Investigation on Squeal and Chatter Phenomena in Bicycle Disk Brakes (Part 2, Generation Mechanisms of Squeal and Chatter and Their Countermeasures) (in Japanese), Trans. JSME, Series C, Vol.70, No.689 (2004), pp.38-45.

( 8 ) Mansour, W. M., Quenching of limit cycles of a van der Pol oscillator, Journal of Sound and Vibration, 25(3), (1972), 395-405. 